\title{
Inter -Linkages Between Climate Change Vulnerability and Inequality an Empirical Study Across Hill, Foothill, Drought and Coastal Regions of West Bengal, India
}

\author{
Uttam Haldar $^{1 *}$ - Aishwarya Basu ${ }^{2}$ \\ ${ }^{1}$ Department of Economics, Serampore Girls' College, Hooghly, West Bengal \\ ${ }^{2}$ Department of Economics, Calcutta University, West Bengal \\ *Corresponding Author Email id: u12haldar@gmail.com
}

Received: 02.05.2021; Revised: 14.05.2021; Accepted: 29.05.2021

CSociety for Himalayan Action Research and Development

\begin{abstract}
India is one of the vulnerable countries in the world in terms of climate events. The poor people and poor regions are badly affected by climate change. On the other hand, the reduction of vulnerability received a top priority in the Sustainable Development Goals of the United Nations. The present paper attempts to examine the inter-linkages between climate change vulnerability and inequality empirically across four agro-climatic regions of West Bengal like hill, foothill, drought and coastal regions. Vulnerability in the present paper is measured by adopting composite livelihood vulnerability index and income (consumption) inequality is measured by Gini coefficient. This is an empirical paper based on primary data collected from 627 households over 15 villages in different agro-climatic regions of West Bengal during 2018- 2019. The result of the paper showed that there is a positive correlation relation between income inequality (consumption) and vulnerability. The higher inequality is accompanied by higher vulnerability and vice versa. The study draws an important policy implication for reduction of vulnerability as well as reduction of inequality. The poverty reduction measures are not sufficient to reduce inequality i.e., if inequalities are on the rise the anti-poverty measures cannot reduce such inequality.
\end{abstract}

Keywords: Livelihood Vulnerability Indices $\bullet$ Inequality $\bullet$ Agro-Climatic Regions $\bullet$ Correlation $\bullet$ Gini Coefficient - Anti- Poverty Measures $\bullet \mathrm{JEL} \bullet \mathrm{Q} 54 \bullet \mathrm{O} 15$,

\section{Introduction}

India is one of the most climate vulnerable countries in the world and her rank in the global index is 5 th with respect to extreme weather events in 2018 (Tripathi, 2019). The poorest of the poor are at risk due to climate changein India. The present paper tries to examine thenexus between climate change vulnerability and inequality within the country. The Fourth Assessment Report of Intergovernmental Panel on Climate Change (IPCC) highlighted that the victims of climate change are among socially, economically viable and marginalized sections of the people. The negative impacts of climate change are more heavily towards the poor than the rich and the poor regions are affected more than the prosperous regions (Skoufias, 2012). The causes of vulnerability are of greater exposure to climate change hazard and low accessibility to shelter in low risk environment (Douglas et al.,2008). On the other hand, wealthier are able to sustain quickly more adaptation measures (Cutter et al., 2007).It is important to mention that some studies 
are available relating to climate change vulnerability in different geographical regions in the global and national levels like flood prone coastal regions (Huyanh and Stringer, 2018), Himalayan region (Koirala 2015; Panthi et al., 2015; Ives et al., 2000; Liu and Rasul, 2007), African continent (Adu et.al., 2017; IPCC, 2007), Small Caribbean Island (Schneider, 2007; McWilliams et al., 2005), and wet lands of South America (Shah et al., 2013). The term vulnerability is multidimensional nature (Alwang et al., 2001; Adger, 2006). Sustainable livelihood framework of Hahn et al. (2009) tries to integrate the interaction between the humanbeing and its social and physical environment. On the other hand, the Intergovernmental Panel on Climate Change (IPCC) framework approach defines exposure, sensitivity and adaptive capacity as three major factors of vulnerability (Sisay, 2016). We have gone through some literature on inequalityfocusing on material aspects of income inequality (Ward and Shively, 2012; Bohle et al., 1994). There are various types of inequality prevailing within the country level. First, inequality is based on demographic factors like gender, age and religion etc. Secondly, inequality may be of income and assets. Thirdly, inequality is in terms of access to public resources like health, education and housing etc. Unequal distribution of wealth may lead to vulnerability(Burton, 1997). Inequality enhanced vulnerability in a vicious cycle in which higher the inequality higher is the exclusion and higher will be vulnerability (Rothstein and Uslaner, 2005).

A large number of studies have focused on the relationship between poverty and climate change vulnerability (Ahmed et al., 2011; Hardoy and Pandiella, 2009), but the study of inequality has remained under discussion in the academic literature. Even the study of inter-linkages between climate change vulnerability and inequality has received a less attention in India in general and West Bengal in particular. The study of inequality is significant in the context of sustainable development goals (SDGs) 10 of the United Nation Development Programme (UNDP) which emphasized the reduction of inequalities within and among countries.

Given the above backdrop, the objectives of the paper are the following.

First, is to measure the climate change vulnerability of the households with the help of livelihood vulnerability index across hill, foothill, drought and coastal regions of West Bengal.

Second, is to measure income (consumption) inequality using Gini coefficient across different agro-climatic regions of West Bengal.

Third, is to examine the nexus between climate change vulnerability and inequality across different agro-climatic regions of West Bengal.

\section{Material and Methods Study Area}

The study has been conducted across four different agro-climatic regions of West Bengal India. The selected agro-climatic regions are hill region of Darjeeling district, foot hill region of Jalpaiguri district, drought regionof Purulia district and coastal region of Indian Sundarban in South 24 Parganas district of West Bengal. These four districts are climate sensitive districts of the state of West Bengal.Darjeeling district is the northern district of West Bengal. Most of the part of Darjeeling is located in mountain range. Its ecological diversity is attractive to the tourist. Forestry, tea garden and tourism are the pillar of the economy of Darjeeling district. Jalpaiguri district is located in foothill region. It is the entry point of north eastern part of India. Due to the maximum rainfall weather is humid and moist, which is the source of vast area of evergreen and deciduous forest in this district. Rivers in this district are flood prone. Forestry,tea garden, agriculture are the main occupations to the people. Due to located in tropical zone, Purulia district is 
the most drought prone area in West Bengal. Soil of the Purrulia district is mainly residual formed from bed rocks by weathering and is comparatively less-fertile. Mono-cropping agriculture and forestry are the major sources of occupation. Coastal regions of Sundarban, South 24 Parganas districtis characterized by tropical cyclones, storm surges, land subsidence, sea level rise, coastal erosion and coastal inundation (Dey et al. 2016). The climatic conditions in terms of average temperature, maximum and minimum temperatures, average rainfall and average evaporation across different regions over more than 100 (1901-2002) years are presented in Table 1. Season-wise average temperature and average rainfall across different regions over more than 100 (1901-2002) years are shown in Table 2. The trends in potential evaporation, crop evaporation and vapour pressure over the period 1901 to 2002 are shown in the appendix

Table 1: Climate variables across various agro-climatic regions of West Bengal

\begin{tabular}{|c|c|c|c|c|c|c|c|c|c|c|}
\hline \multirow[b]{2}{*}{ Regions } & \multicolumn{2}{|c|}{$\begin{array}{c}\text { Average } \\
\text { temperature } \\
\left({ }^{0} \mathrm{C}\right)\end{array}$} & \multicolumn{2}{|c|}{$\begin{array}{c}\text { Maximum } \\
\text { temperature } \\
\left({ }^{0} \mathrm{C}\right)\end{array}$} & \multicolumn{2}{|c|}{$\begin{array}{c}\text { Minimum } \\
\text { temperature } \\
\left({ }^{0} \mathrm{C}\right)\end{array}$} & \multicolumn{2}{|c|}{$\begin{array}{c}\text { Average } \\
\text { Rainfall } \\
(\mathbf{m m})\end{array}$} & \multicolumn{2}{|c|}{$\begin{array}{c}\text { Average } \\
\text { Evaporation } \\
(\mathbf{m m} / \mathbf{d a y})\end{array}$} \\
\hline & 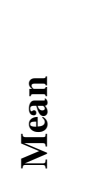 & 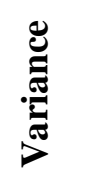 & 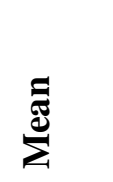 & 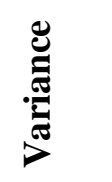 & $\sum_{\Sigma}^{\Xi}$ & 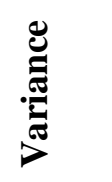 & $\sum^{\Xi}$ & 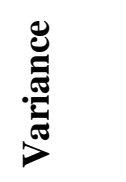 & 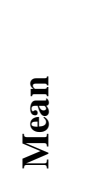 & 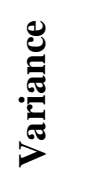 \\
\hline Darjeeling & 22.89 & 0.125 & 28.28 & 0.137 & 17.54 & 0.169 & 174.90 & 519.40 & 4.00 & 0.005 \\
\hline Jalpaiguri & 24.35 & 0.129 & 29.57 & 0.139 & 19.16 & 0.178 & 195.23 & 634.06 & 4.06 & 0.005 \\
\hline Purulia & 25.41 & 0.121 & 31.25 & 0.181 & 19.60 & 0.174 & 109.85 & 281.57 & 4.59 & 0.012 \\
\hline Sundarban & 21.71 & 0.071 & 24.70 & 0.107 & 18.75 & 0.094 & 116.96 & 424.77 & 3.02 & 0.009 \\
\hline
\end{tabular}

Source: author's calculation from secondary data source of Indian Meteorological Department, Pune.

\section{Data}

The study is based on primary data collected from purposively selected five agro-climatic regions of West Bengal. 15 Villages are selected on the basis climate sensitiveness and $10 \%$ of households from each village are selected in probability proportionate to different livelihood groups as per their major occupation. Thus, total 627 households have been selected from 15 villages across fourdifferent agro-climatic regions of West Bengal. An interview method has been applied to collect data. In addition to the selected households, we discussed with the local people and interviews with local experts and school teachers and other knowledgeable elders in the villages. The selection of sample villages and sample households are shown in Table 3. 
J. Mountain Res. P-ISSN: 0974-3030, E-ISSN: 2582-5011

Vol. 16(1), (2021), 77-92

DOI: https://doi.org/10.51220/jmr.v16il.7

Table 2: Season wise average temperature and average rainfall across various agro-climatic regions of West Bengal

\begin{tabular}{|c|c|c|c|c|c|c|c|c|}
\hline \multirow[b]{2}{*}{ Regions } & \multicolumn{4}{|c|}{ Season wise average temperature $\left({ }^{0} \mathrm{C}\right)$} & \multicolumn{4}{|c|}{ Season wise average Rainfall $(\mathrm{mm})$} \\
\hline & $\begin{array}{l}\text { Pre- } \\
\text { Monsoo } \\
\mathrm{n} \\
\text { (Mar- } \\
\text { May) }\end{array}$ & $\begin{array}{l}\text { Monsoo } \\
\text { n (Jun- } \\
\text { Sep) }\end{array}$ & $\begin{array}{l}\text { Post- } \\
\text { Monsoo } \\
\text { n (Oct- } \\
\text { Dec) }\end{array}$ & $\begin{array}{l}\text { Winter } \\
\text { (Jan- } \\
\text { Feb) }\end{array}$ & $\begin{array}{l}\text { Pre- } \\
\text { Monsoo } \\
\text { n (Mar- } \\
\text { May) }\end{array}$ & $\begin{array}{l}\text { Monsoo } \\
\text { n (Jun- } \\
\text { Sep) }\end{array}$ & $\begin{array}{l}\text { Post- } \\
\text { Monsoo } \\
\text { n (Oct- } \\
\text { Dec) }\end{array}$ & $\begin{array}{l}\text { Winter } \\
\text { (Jan-Feb) }\end{array}$ \\
\hline $\begin{array}{l}\text { Darjeelin } \\
\mathrm{g}\end{array}$ & 24.26 & 26.88 & 20.83 & 15.94 & 86.87 & 424.96 & 38.05 & 12.12 \\
\hline Jalpaiguri & 25.66 & 28.18 & 22.32 & 17.75 & 110.74 & 465.06 & 43.73 & 9.55 \\
\hline Purulia & 29.52 & 28.29 & 21.49 & 19.34 & 37.15 & 265.87 & 31.75 & 24.02 \\
\hline $\begin{array}{l}\text { Sundarba } \\
\mathrm{n}\end{array}$ & 23.69 & 23.72 & 19.75 & 17.65 & 48.46 & 262.72 & 58.71 & 15.57 \\
\hline
\end{tabular}

Source: author's calculation from secondary data source of Indian Meteorological Department, Pune.

Table 3: Distribution of sample households ( $\mathrm{HH})$ across different agro-climatic regions of West Bengal

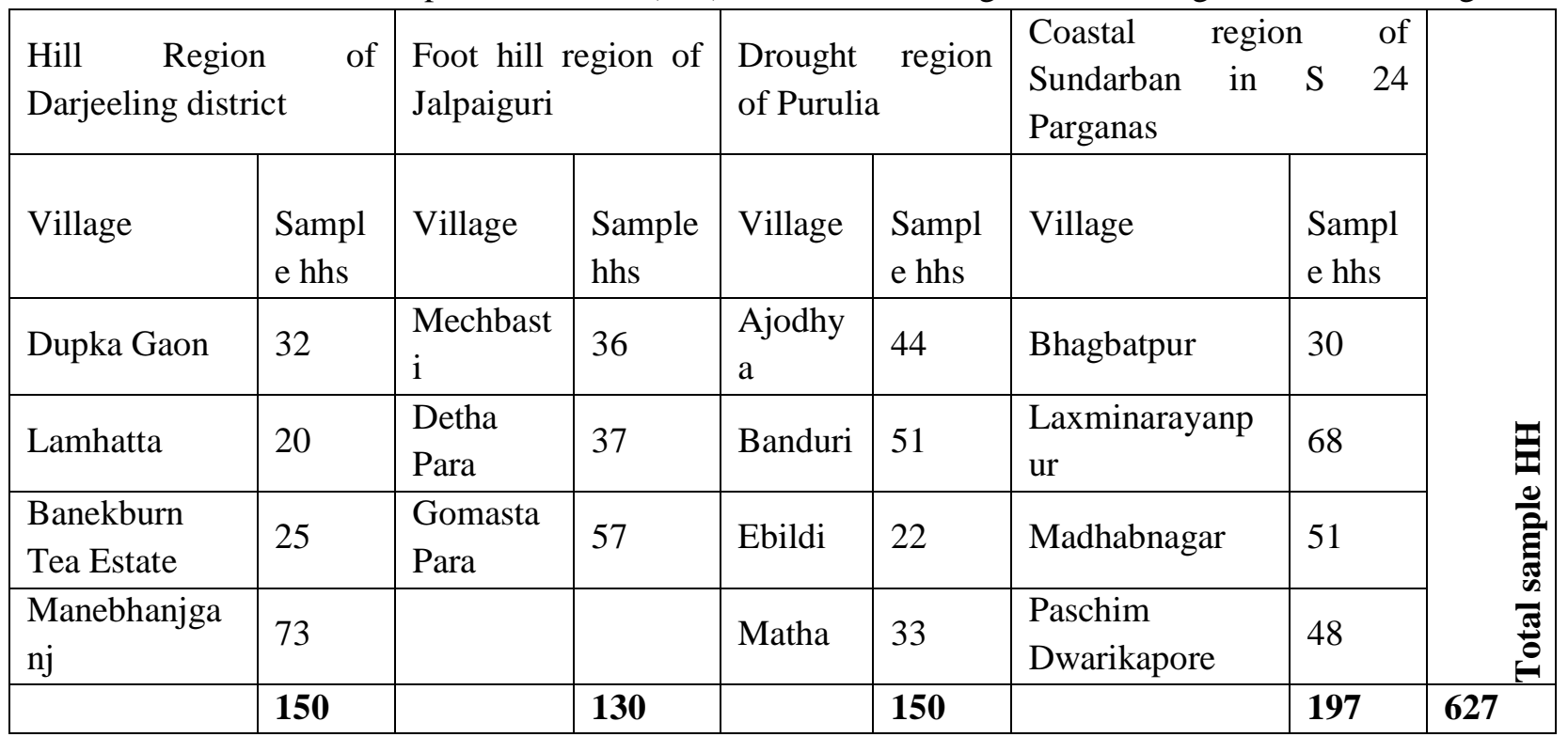

Source: Calculated by authors from primary data

\section{Analytical Methods}

\section{Livelihood Vulnerability Index}

To measure the vulnerability the present paper utilizes Livelihood Vulnerability Index (LVI). It is a composite index which is constructed with 8 sub-components namely, Socio Demographic Profile (SDP), Livelihood Strategies (LS), Food,
Social Network (SN), Natural Capital (NC), Water, Health and Climatic Variables (CV)(Hahn et al., 2009). Each of the sub component indexes is again built with several indicators. The present study chooses indicators in such a way so that they can reflect the standard of living of the people of the study area. Using the methodology of Human Development Index (UNDP, 2006) the 
present study normalise each indicators in unit free scale ranging 0 to 1 . Following by Iyenger and Sudarshan (1982), weighted vulnerability index $\left(\overline{y_{2}}\right)$ of each subcomponent is measured with following formula:

$\overline{y_{h}}=\frac{\sum_{j=1}^{k} w_{j} x_{i j}}{\sum_{j=1}^{k} w_{j}}$.

Where, $\mathrm{Xij}$ is the normalized score of jth indicator and the weights of jth indicators $\left(w_{j}\right)$ is determined by $\quad w_{j}=\frac{c}{\sqrt{\operatorname{var}\left(x_{i j}\right)}} \quad$ such that $\left(0<w<1\right.$ and $\left.\sum_{j=1}^{k} w_{j}=1\right)$, in which $\mathrm{c}$ is the normalizing constant calculated by $c=\left[\sum_{j=1}^{j=k} \frac{1}{\sqrt{\operatorname{var}\left(x_{i j}\right)}}\right]^{-1}$

After calculating weighted vulnerability index $\left(\overline{y_{k}}\right)$ of 8 sub components, livelihood vulnerability index (LVI) is computed by weighted mean as follows:

$L V I=\frac{\sum_{i=1}^{g} W_{i} \overline{Y_{2}}}{\sum_{i=1}^{\mathrm{g}} W_{i}}=\frac{\sum_{i=1}^{\mathrm{g}} \overline{Y_{2}}}{8}\left(\cdots w_{i}=\sum_{j=1}^{k} w_{j}=1\right)$

The value of LVI varies in the scale of 0 (lowest vulnerability) to 1(highest vulnerability).

3.2 Gini coefficient: To measure inequality the present paper is based on widely used technique Gini coefficient. Inequality is measured from income side and from consumption side. Its value varies from 0 (lowest inequality) to 1(highest inequality).

The relation between vulnerability and inequality has been measured by the correlation coefficient.

\section{Results and Discussions}

The degree of vulnerability of the households is measured by composite livelihood vulnerability index of Hahn et al.,(2009).The detailed calculation of livelihood vulnerability indices of the households across four agro-climatic regions of West Bengal is given in the appendix . The sub components of LVI consists of socio demographic profile (SDP), livelihood strategy (LS), food, social network (SN), water, health and climate variables (CV). The results of LVI of the households in different sub components and composite LVI are presented in Table 4. From this Table 4 it is found that the composite livelihood vulnerability index of the households in the drought region of Purulia district is highest (0.6076), followed by the coastal Sunderban (0.5980), hill region of Darjeeling district (0.5866) and foothill region of Jalpaiguri district (0.5505).

Table 4: Composite Livelihood Vulnerability Index (LVI) of the households across four regions of West Bengal

\begin{tabular}{lllll}
\hline $\begin{array}{l}\text { Sub } \\
\text { components } \\
\text { LVI }\end{array}$ & Jalpaiguri & Darjeeling & Sundarban & Purulia \\
\hline SDP Index & 0.2628 & & & \\
LS Index & 0.7248 & 0.3043 & 0.3620 & 0.3375 \\
Food Index & 0.9724 & 0.6756 & 0.7071 & 0.6664 \\
SN Index & 0.4790 & 0.9732 & 0.9137 & 0.8167 \\
NC Index & 0.7885 & 0.6614 & 0.6288 & 0.4774 \\
Water Index & 0.3913 & 0.7264 & 0.7661 & 0.9116 \\
Health Index & 0.2784 & 0.4386 & 0.3265 & 0.6286 \\
CV Index & 0.5070 & 0.2864 & 0.5161 & 0.4526 \\
Composite LVI & 0.5505 & 0.6270 & 0.5638 & 0.5700 \\
\hline Souce: Calcul & 0.5866 & 0.598 & 0.60761 \\
\hline
\end{tabular}

Source: Calculated by authors from primary data 
The inequality of the households across different agro-climatic regions is measured by Gini coefficient. Gini coefficient is calculated on the basis of income and consumption expenditure. The monthly per capita income (MPCE) and monthly per capita consumption expenditure (MPCE) of the households across different regions are presented in Table 5. From Table 5 it is observed that per capita income and per capita consumption is lowest for the drought region of Purulia district while they are highest for the hill region of Darjeeling district. Monthly per capita consumption expenditure on various items across different regions is shown in the appendix.

In order to calculate income Gini coefficientand consumption Gini coefficientwe have arranged the households of each region in 10 groups (decile) in descending order of monthly per capita income and monthly per capita consumption respectively. The values of income Gini coefficient and consumption Gini coefficient across different regions are presented in Table 4.In terms of income Gini coefficient the households in coastal region of Sunderban is found to be highest inequality (0.587), followed by the households in the drought region of Purulia district (0.572), the hill region of Darjeeling district (0.561) and the foothill region of Jalpaiguri district (0.526). Similarly, in terms of consumption Gini coefficient values, the drought region of Purulia district is observed to be highest inequality (0.464), followed by hill region of Darjeeling district (0.45), the coastal region of
Sunderbans(0.439) and the foothill region of Jalpaiguri district(0.375)(Table 6). The cumulative percentage of households and cumulative percentage of income group for the measurement of Lornez curve is shown in Table 7 and Figure (1).

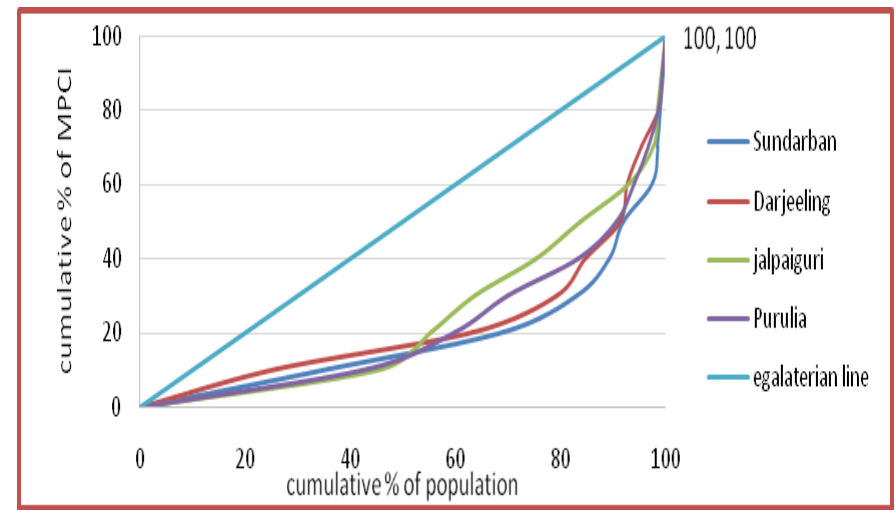

Figure 1: Lorenz curves (income distribution) of four different climatic regions of West Bengal.

Table 5: Monthly per capital income and consumption expenditure of the households across different regions of West Bengal

\begin{tabular}{lll}
\hline Regions & $\begin{array}{l}\text { Monthly } \\
\text { per capita } \\
\text { income (Rs) }\end{array}$ & $\begin{array}{l}\text { Monthly per } \\
\text { capita } \\
\text { consumption } \\
\text { expenditure } \\
\text { (Rs) }\end{array}$ \\
\hline Jalpaiguri & 1338.28 & 993.59 \\
Darjeeling & 3996.00 & 1811.19 \\
Sundarban & 1701.88 & 1102.62 \\
Purulia & 809.21 & 795.59 \\
\hline
\end{tabular}

Source: Author's calculation from primary data

Table 6: Income inequality and consumption inequality across different regions of West Bengal

\begin{tabular}{lll}
\hline Region & $\begin{array}{l}\text { Income inequality } \\
\text { (Gini coefficient) }\end{array}$ & $\begin{array}{l}\text { Consumption inequality } \\
\text { (Gini coefficient) }\end{array}$ \\
\hline Jalpaiguri & $0.526(4)$ & $0.375(1)$ \\
Darjeeling & $0.561(3)$ & $0.45(2)$ \\
Sundarban & $0.587(1)$ & $0.439(3)$ \\
Purulia & $0.572(2)$ & $0.464(1)$ \\
\hline
\end{tabular}

Source: Author's calculation from primary data, Note: () shows rank. 
Table 7: Cumulative distribution of income and households across different regions of West Bengal

\begin{tabular}{|c|c|c|c|c|c|}
\hline $\begin{array}{l}\text { Decile } \\
\text { groups }\end{array}$ & $\begin{array}{l}\text { Cumulative } \% \\
\text { of MPCI }\end{array}$ & Sundarban & Darjeeling & Jalpaiguri & Purulia \\
\hline 1 & $\leq 10 \%$ & 36.04 & 26.00 & 46.15 & 43.33 \\
\hline 2 & $\leq 20 \%$ & 69.04 & 63.33 & 55.38 & 60.00 \\
\hline 3 & $\leq 30 \%$ & 83.25 & 79.33 & 63.85 & 70.00 \\
\hline 4 & $\leq 40 \%$ & 89.34 & 84.67 & 75.38 & 83.33 \\
\hline 5 & $\leq 50 \%$ & 91.88 & 91.33 & 83.85 & 90.67 \\
\hline 6 & $\leq 60 \%$ & 97.46 & 92.67 & 93.08 & 94.00 \\
\hline 7 & $\leq 70 \%$ & 98.48 & 95.33 & 97.69 & 96.67 \\
\hline 8 & $\leq 80 \%$ & 98.98 & 98.67 & 98.46 & 98.67 \\
\hline 9 & $\leq 90 \%$ & 99.49 & 99.33 & 99.23 & 99.33 \\
\hline 10 & $\leq 100 \%$ & 100.00 & 100.00 & 100.00 & 100.00 \\
\hline
\end{tabular}

Source: Calculated by authors from primary data

The cumulative percentage of households and the measurement of Lornez curve is shown in cumulative percentage of consumption group for

Table 8 and Figure (2).

Table 8: Cumulative distribution of consumption and households across different regions of West Bengal

\begin{tabular}{|c|c|c|c|c|c|}
\hline $\begin{array}{l}\text { Decile } \\
\text { groups }\end{array}$ & $\begin{array}{l}\text { Cumulative } \% \\
\text { of MPCE }\end{array}$ & Jalpaiguri & Sundarban & Darjeeling & Purulia \\
\hline 1 & $\leq 10 \%$ & 7.7 & 23.4 & 18.7 & 10 \\
\hline 2 & $\leq 20 \%$ & 25.4 & 36.5 & 46 & 39.3 \\
\hline 3 & $\leq 30 \%$ & 53.8 & 59.9 & 66 & 68 \\
\hline 4 & $\leq 40 \%$ & 74.6 & 77.2 & 76 & 86 \\
\hline 5 & $\leq 50 \%$ & 89.2 & 85.3 & 82 & 88 \\
\hline 6 & $\leq 60 \%$ & 92.3 & 92.9 & 90.7 & 96 \\
\hline 7 & $\leq 70 \%$ & 96.9 & 96.4 & 98 & 97.3 \\
\hline 8 & $\leq 80 \%$ & 98.5 & 98.5 & 98.7 & 98 \\
\hline 9 & $\leq 90 \%$ & 99.2 & 99.5 & 99.3 & 99.3 \\
\hline 10 & $\leq 100 \%$ & 100 & 100 & 100 & 100 \\
\hline
\end{tabular}

Relation between Vulnerability and Inequality The relationship between inequality (income and consumption) and vulnerability is measured by the correlation coefficient. The values of the correlation coefficient between inequality and vulnerability of the whole regions under study are presented in Table 9. From Table 9 we find that the values of correlation are positive and significant. This means that high vulnerability is accompanied by high inequality and vice -versa. 
J. Mountain Res. P-ISSN: 0974-3030, E-ISSN: 2582-5011

Vol. 16(1), (2021), 77-92

DOI: https://doi.org/10.51220/jmr.v16il.7

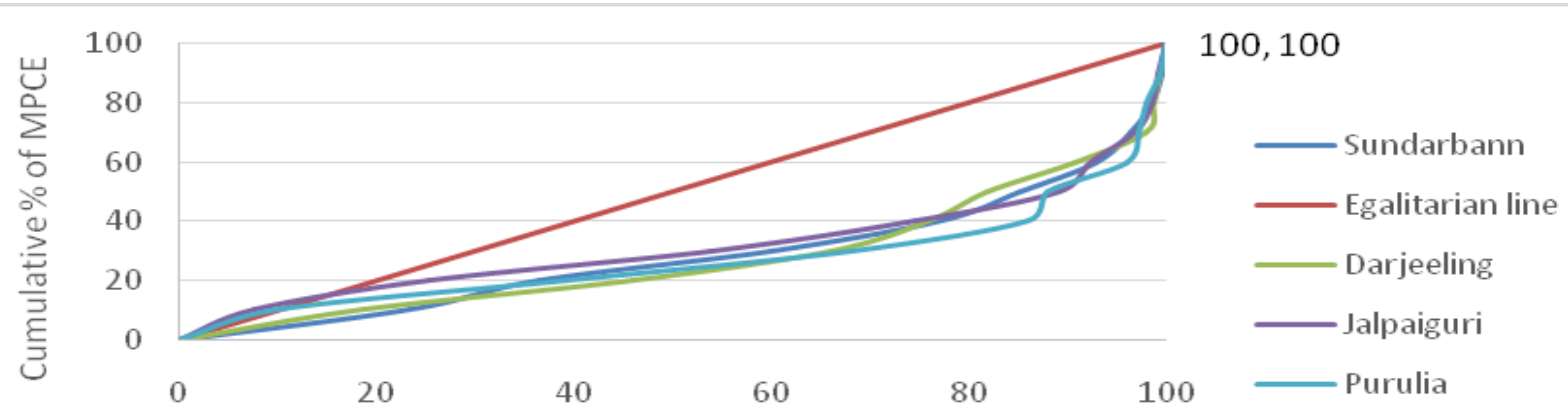

Cumulative $\%$ of population

Figure 2: Lorenz curves (distribution in Consumption) of four districts

Table 9: Correlation between inequality and vulnerability of the four regions as a whole

\begin{tabular}{ll}
\hline Inequality & Vulnerability \\
\hline Income inequality & $0.922^{* *}$ \\
Consumption inequality & $0.963 * * *$
\end{tabular}

Source: author's calculation, $\quad$ Note: $* * *$ and $* *$ show significant at $5 \%$ level and $10 \%$ level respectively.

Figure 3 and vulnerability and consumption

The vulnerability and income inequality across inequality is also given in Figure 4. different regions of West Bengal is shown in

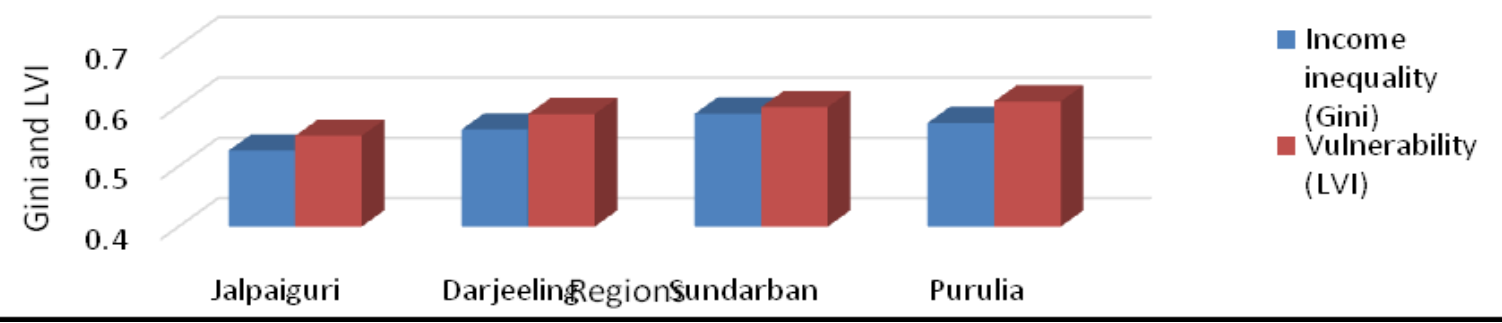

Figure 3: Income inequality and vulnerability across different regions of West Bengal

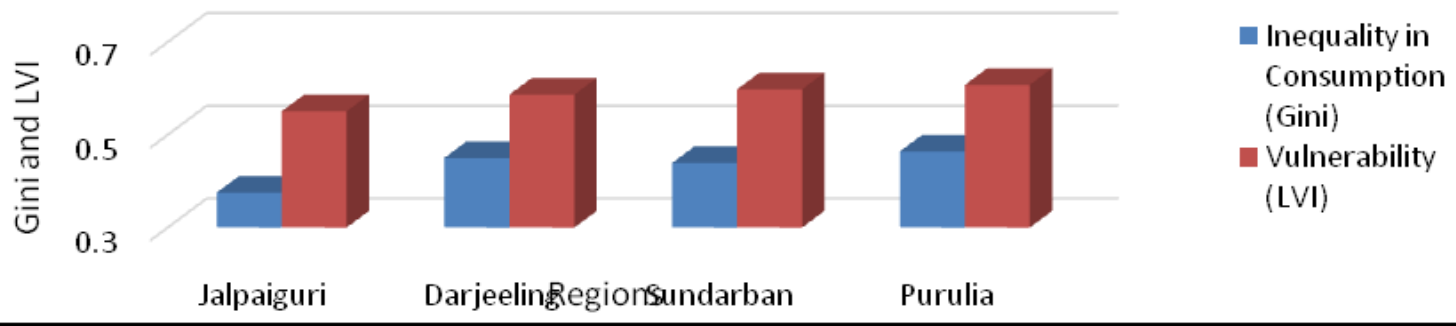

Figure 4: Consumption inequality and vulnerability across different regions of West Bengal 
Table 10: Region wise calculation of different subcomponents of LVI

\begin{tabular}{|c|c|c|c|c|c|c|c|c|c|}
\hline \multirow[b]{2}{*}{ 章 } & \multirow[b]{2}{*}{ Indicators } & \multicolumn{2}{|c|}{ Jalpaiguri } & \multicolumn{2}{|c|}{ Darjeeling } & \multicolumn{2}{|c|}{ Sundarban } & \multicolumn{2}{|c|}{ Purulia } \\
\hline & & LVI & Weight & LVI & Weight & LVI & Weight & LVI & Weight \\
\hline \multirow{10}{*}{ 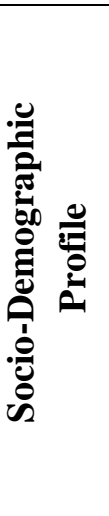 } & Percentage of dependent people $<20$ years, $>60$ years & 0.1 & 0.35 & 0.1 & 0.37 & 0.1 & 0.38 & 0.14 & 0.353 \\
\hline & & 39 & 2 & 298 & 73 & 539 & 48 & 69 & 4 \\
\hline & Percentage of female headed households & 0.0 & 0.13 & 0.0 & 0.15 & 0.0 & 0.16 & 0.04 & 0.188 \\
\hline & & 565 & 59 & 77 & 39 & 543 & 47 & 14 & 3 \\
\hline & Percentage of illiteracy among households head & 0.0 & 0.16 & 0.0 & 0.18 & 0.0 & 0.15 & 0.06 & 0.158 \\
\hline & & 359 & 09 & 401 & 79 & 786 & 49 & 46 & 8 \\
\hline & Percentage of female family earner & 0.0 & 0.35 & 0.0 & 0.28 & 0.0 & 0.29 & 0.08 & 0.299 \\
\hline & & 314 & 11 & 575 & 09 & 752 & 57 & 47 & 6 \\
\hline & SDP Index & 0.2 & & 0.3 & & 0.3 & & 0.33 & \\
\hline & & 628 & & 043 & & 62 & & 75 & \\
\hline \multirow{12}{*}{ 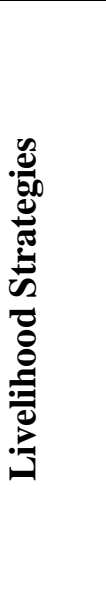 } & Percentage of households with family member working outside local area & 0.0 & 0.15 & 0.0 & 0.11 & 0.0 & 0.08 & 0.02 & 0.109 \\
\hline & & 174 & 06 & 222 & 91 & 312 & 3 & 64 & 9 \\
\hline & Percentage of households change sowing and cropping schedule & 0.0 & 0.09 & 0.0 & 0.09 & 0.1 & 0.12 & 0.03 & 0.097 \\
\hline & & 504 & 64 & 458 & 28 & 054 & 07 & 52 & 8 \\
\hline & Livelihood diversification index & 0.2 & 0.28 & 0.1 & 0.17 & 0.1 & 0.21 & 0.12 & 0.200 \\
\hline & & 538 & 04 & 203 & 86 & 23 & 3 & 86 & 2 \\
\hline & Average livestock diversification index & 0.0 & 0.14 & 0.0 & 0.17 & 0.0 & 0.17 & 0.13 & 0.191 \\
\hline & & 943 & 71 & 969 & 58 & 925 & 61 & 84 & 4 \\
\hline & Monthly per capita income (Rs) & 0.3 & 0.32 & 0.3 & 0.43 & 0.3 & 0.40 & 0.33 & 0.400 \\
\hline & & 089 & 55 & 904 & 36 & 55 & 72 & 78 & 8 \\
\hline & LS Index & 0.7 & & 0.6 & & 0.7 & & 0.66 & \\
\hline & & 248 & & 756 & & 071 & & 64 & \\
\hline
\end{tabular}




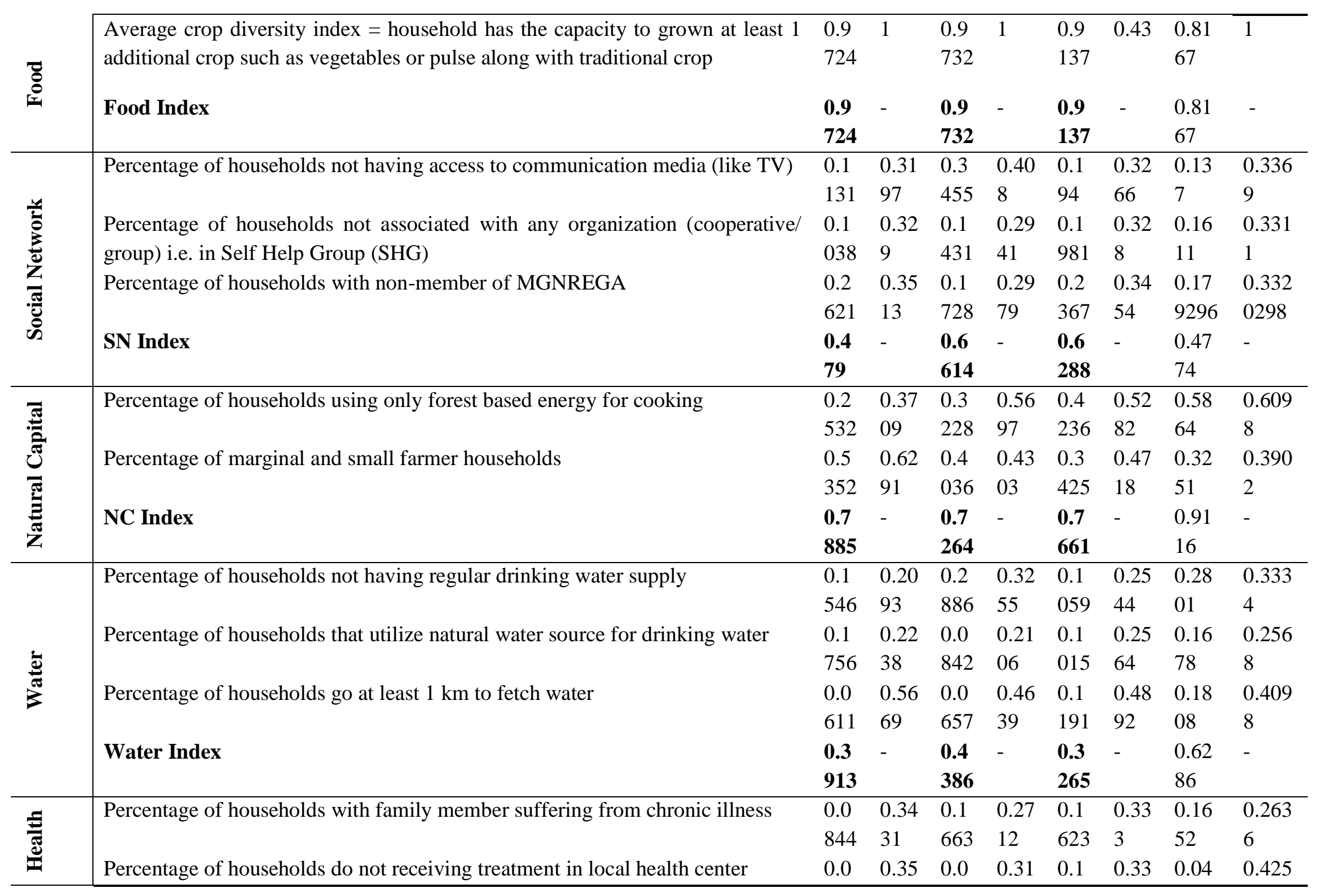




\begin{tabular}{|c|c|c|c|c|c|c|c|c|c|}
\hline & & 809 & 07 & 729 & 22 & 76 & 34 & 25 & 1 \\
\hline & Percentage of households do not have toilet facility & 0.1 & 0.30 & 0.0 & 0.41 & 0.1 & 0.33 & 0.24 & 0.311 \\
\hline & & 131 & 62 & 472 & 66 & 778 & 36 & 49 & 3 \\
\hline & Health Index & 0.2 & - & 0.2 & - & 0.5 & - & 0.45 & - \\
\hline & & 784 & & 864 & & 161 & & 26 & \\
\hline \multirow{10}{*}{ 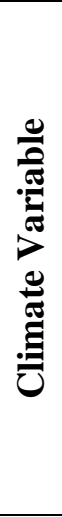 } & \multirow[t]{2}{*}{ Percentage of households realize reduction in rainfall in past 5 years } & 0.0 & 0.26 & 0.1 & 0.25 & 0.1 & 0.25 & 0.07 & 0.229 \\
\hline & & 391 & 77 & 769 & 76 & 511 & 22 & 97 & 8 \\
\hline & \multirow{2}{*}{$\begin{array}{l}\text { Percentage of households about the perception of landslide increased in last } 5 \\
\text { years }\end{array}$} & 0.2 & 0.32 & 0.1 & 0.25 & 0.1 & 0.24 & 0.27 & 0.315 \\
\hline & & 965 & 67 & 665 & 23 & 39 & 89 & 1 & 2 \\
\hline & \multirow{4}{*}{$\begin{array}{l}\text { Percentage of households about the perception of storm increased in last } 5 \\
\text { years } \\
\text { Percentage of households that did not receive warning about natural disasters }\end{array}$} & 0.0 & 0.21 & 0.1 & 0.25 & 0.1 & 0.25 & 0.07 & 0.229 \\
\hline & & 574 & 32 & 641 & 11 & 495 & 17 & 97 & 8 \\
\hline & & 0.1 & 0.19 & 0.1 & 0.23 & 0.1 & 0.24 & 0.13 & 0.225 \\
\hline & & 14 & 24 & 195 & 9 & 242 & 72 & 97 & 3 \\
\hline & \multirow[t]{2}{*}{ CV Index } & 0.5 & - & 0.6 & - & 0.5 & - & 0.57 & - \\
\hline & & 070 & & 270 & & 638 & & 00 & \\
\hline & \multirow[t]{2}{*}{ LVI } & 0.5 & - & 0.5 & - & 0.5 & - & 0.60 & - \\
\hline & & 505 & & 866 & & 98 & & 76 & \\
\hline
\end{tabular}

Source: Computed by authors from primary data

Table 11: Monthly Per Capita Consumption Expenditure (MPCE) (Rs) on different items

\begin{tabular}{|c|c|c|c|c|c|c|c|c|c|c|c|c|}
\hline & Cereal & Pulses & $\begin{array}{l}\text { Edible } \\
\text { Oil }\end{array}$ & Vegetables & $\begin{array}{l}\text { Egg, } \\
\text { Meat, } \\
\text { Fish }\end{array}$ & Spice & Fuel & Dress & Travel & Education & Medical & MPCE \\
\hline Darjeeling & 68 & 54 & 141 & 78 & 300 & 25 & 209 & 260 & 212 & 267 & 197 & 1811 \\
\hline Jalpaiguri & 73.58 & 84.03 & 95.57 & 123.22 & 169.12 & 61.29 & 115.22 & 63.62 & 69.72 & 76.02 & 62.21 & 993.59 \\
\hline Purulia & 77.5 & 57.2 & 69.69 & 98.41 & 155.3 & 36.3 & 102.35 & 64 & 59.97 & 37.87 & 37.01 & 795.59 \\
\hline Sundarban & 133.2 & 88.8 & 111.6 & 64.11 & 191.71 & 85.77 & 102.7 & 70.71 & 46.58 & 68.98 & 138.38 & 1102.6 \\
\hline
\end{tabular}

Source: Computed by authors from primary data 
From figure 4 we find that the drought region of Purulia district has higher inequality with higher vulnerability while the foothill region of Jalpaiguri district has lower inequality with lower vulnerability.

The high consumption inequality with high vulnerability in the drought region of Purulia district seems to be higher climate exposure and lower adaptive capacity. The people in the drought region district of Purulia experiences high poverty as reflected by low per capita consumption expenditure and low per capita income. This region is characterized by deficient along with high inequality. water and lack of irrigation and high temperate region. Agriculture is not efficient although people are dependent on it. In addition, there is a scarcity of off farm employment opportunity to the people. On the other hand, the people in Purulia district have low adaptive capacity like lack of education, lack of health facility, poor quality of housing, very low land holding, low income opportunity, low employability etc., through which they are unable to cope with the adverse effect of climate change and these led to high

vulnerability

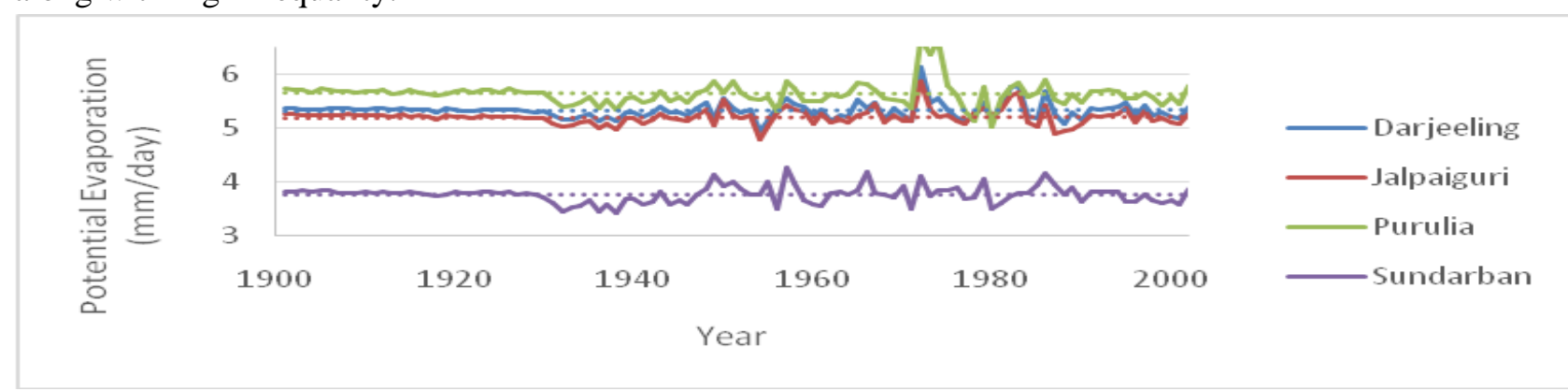

Figure 5: Trends in potential evaporation

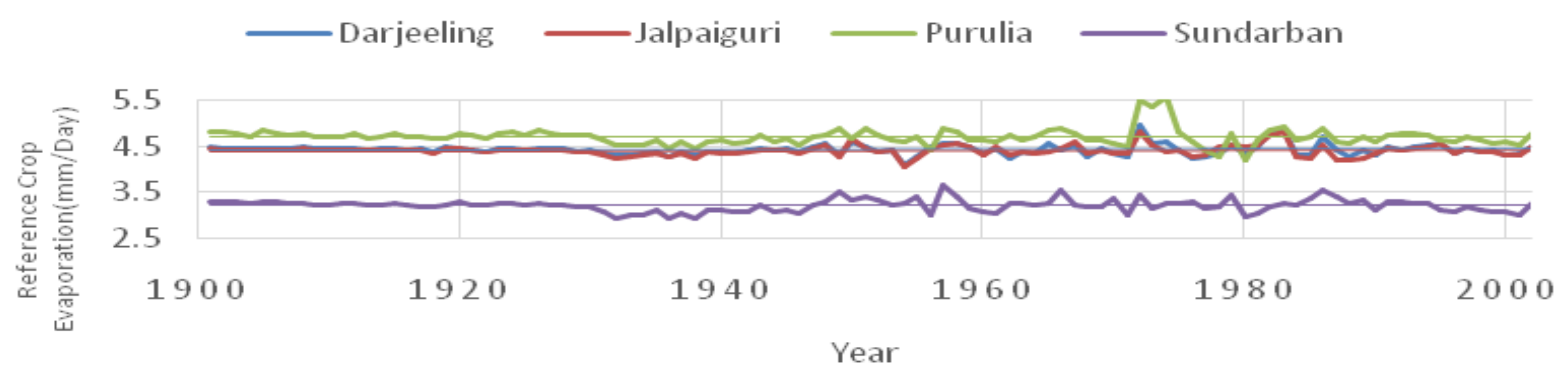

Figure 6: Trends in reference crop evaporation

\section{Discussion}

The findings of the present papermay support or contradict the results of others. The result of the present paper supports the results of (Wodon et al.,2014) in Egypt, the Surian Arab Republic, Algeria, Morrocco and Yemen. In a study of mountain region of Nepal, it was revealed that low income households are of more exposed to climate hazard than the richer households (Gentle et al., 2014). The study of Uganda, Hill and Mejia-Mantilla (2015) have shown that farmers of the lower income class have the limited capacity to alter cropping patterns, limited accessibility to water reservoirs and agriculture extension services, lesser financial ability to use water saving techniques compared to the richer farmers. As a result of the scarcity of rainfall, the low income farmers are affected much more than the 
high income farmers. The study of (Patankar2015) showed that the poor households with poor quality of shelter exposed highly to flood in Mumbai and they had to incur more money for the protection of their shelters during the flood compared to the wealthy families.

The results of Carter et al., (2007) have shown that people in Honduras are affected by storm causing more damage of asset of the households. The Cyclone Aila2009 has damaged the structure of houses in Bangladesh which is reported to be greater among BPL households (Roy etal., 2007). The findings of Heinrigs(2010) revealed that livelihoods of major sections of population in Sahel region of Africa are dependent on the nature and pattern of rainfall. The findings of the present paper also supported the results of (Adepetu and Berthe, 2007) in which assets poor households, weak health status and lack of education are more prone to hazards of climate change. It is noted that inequality is related to the vulnerability and it creates imbalances in the society (Ward and Shively 2012). The findings of the paper supported the results of (Adger, 1999) where income inequality due to climate change is explained by the lack of access to resources and income poverty. The value of income Gini coefficient (0.51) in Papua New Guinen showed high income inequality (World Bank, 2014). The poor households are more exposed and sensitive to climate hazards and have low adaptive capacity (Gallopin, 2006).

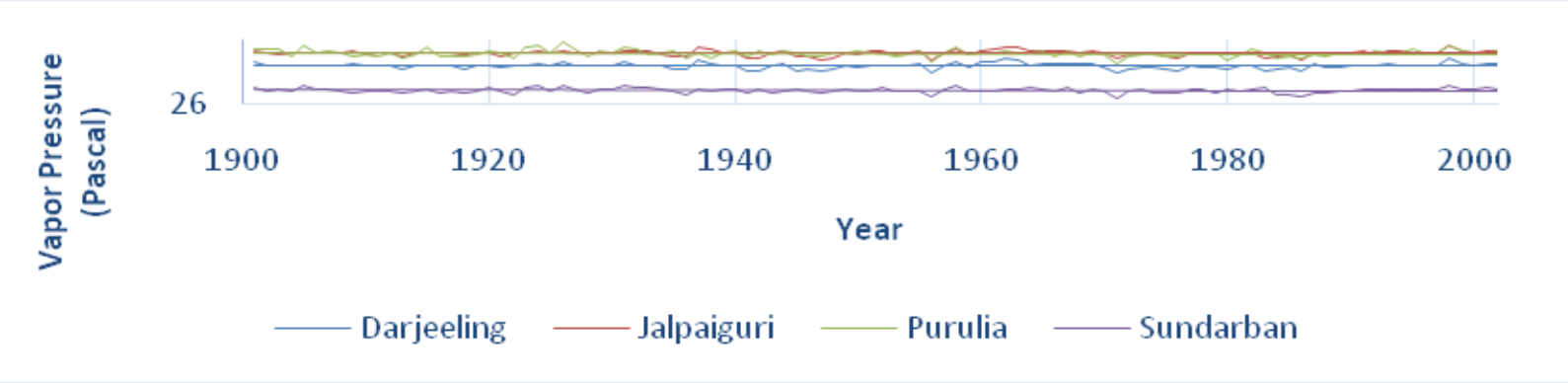

Figure 7: Trends in vapour pressure

The people who are living in the slum areas in Mumbai reported to be a greater incidence of susceptible to diseases mainly water borne in the wake of monsoon floods (Hallegatte et al., 2016). The average value of Gini coefficient in Bangladesh over 2005-2010 reached at 0.45. The value of such Gini coefficient in 2016 rose to 0.483. The finding of the present paper on the value of consumption Gini (0.464) in the drought prone district of Purulia is compatible and closer to the Bangladesh.

\section{Conclusions and policy suggestions}

1. The composite livelihood vulnerability index of the households in the drought region of Purulia district is highest (0.607), followed by the coastal Sunderban (0.598), hill region of Darjeeling district (0.586) and foothill region of Jalpaiguri district (0.550).

2. In terms of consumption Gini coefficient, the drought region of Purulia district is observed to be highest inequality (0.464), followed by hill region of Darjeeling district (0.45), the coastal region of Sunderbans( 0.439$)$ and the foothill region of Jalpaiguri district(0.375).

3. There is a positive and significant relation between inequality and vulnerability. The drought region of Purulia district has high inequality with high vulnerability while the foothill region of Jalpaiguri district has low inequality with low vulnerability.

4. The paper identifies the key to vulnerabilities and inequalities in the drought 
region. These are insufficiency of job, low adaptive capacity like lack of education, lack of health facility, poor quality of housing, very low land holding, low income opportunity, low employability etc., through which they are unable to cope with the adverse effect of climate change. The paper has an important policy implication for inequality reduction and vulnerability reduction. The poverty reduction measures are not sufficient to reduce inequality. Therefore, priorities should be given on considering with different problems into the planning model.

\section{References}

Adepetu AA and Berthe A (2007) Vulnerability of Rural Sahelian Households to Drought: Options for Adaptation, Final Report Submitted to Assessments of Impacts and Adaptations to Climate Change (AIACC), Project No. AF 92. Washington, D.C.: International START Secretariat.

Adger WN (1999) Social vulnerability to climate change and extremes in coastal Vietnam, World Dev., https://doi.org/10.1016/S0305750X(98)00136-3

Adger WN (2006). Vulnerability. Global Environmental Change,http:// dx.doi.org/ 10.1016/j.gloenvcha. 2006.02.006

Adu DT, Kuwornu JKM, Anim-Somuah, H, Sasaki N (2017) Application of livelihood vulnerability index in assessing smallholder maize farming households' vulnerability to climate change in Brong-Ahafo region of Ghana. Kasetsart J Soc. Sci, http://dx.doi.org/10.1016/j.kjss.2017.06.009

Ahmed SA, Diffenbaugh NS, Herter TW, Lobell DB, Ramankutty N, Rios AR, et al. (2011) Climate Volatility and Poverty Vulnerability in Tanzania, Global Env. Change, DOI: 10.1016/j.gloenvcha.2010.10.003

Alwang J, Siegel PB, \& Jorgensen SL (2001) Vulnerability: a view from different disciplines. Discussion paper. Social Protection Unit, World Bank, Washington DC.

Bohle HG, Downing TE, Watts MJ (1994) Climate Change and Social Vulnerability: Toward a Sociology and Geography of Food Insecurity. Global Env. Change, https://doi.org/10.1016/0959-3780(94)90020$\underline{5}$

Burton I (1997) Vulnerability and Adaptive response in the context of Climate and Climate Change. Climate Change, https://doi.org/10.1023/A:1005334926618

Carter M, Peter DL, Tewodaj M, \& Workneh N. (2007). Poverty Traps and Natural Disasters in Ethiopia and Honduras. World Dev. https://doi.org/10.1016/j.worlddev.2006.09.0 $\underline{10}$

Dey S, Ghosh AK, Hazra S (2016). Review of West Bengal State Adaptation Policies. Indian Bengal Delta. DECCMA Working Paper, Deltas, Vulnerability and Climate Change: Migration and Adaptation, IDRC Project Number 107642.

Douglas I, Alam K, Maghenda M, Mcdonnell Y, Mclean Land Campbell J (2008) Unjust waters: climate change, flooding and the urban poor in Africa. Env.Urb., DOI: 10.1177/0956247808089156

Gentle P,Thwaites R, Race D, \& Alexander K (2014). Differential impacts of climate change on communities in the middle hills region of Nepal. Natural Hazards, DOI: 10.1007/s11069-014-1218-0vol. 74, p. 815836.

Hahn MB, Riederer AM, \& Foster SO (2009). The livelihood vulnerability index: A pragmatic approach to assessing risks from climate variability and change - a case study in Mozambique. Glob. Env. Change, https://doi:10.1016/j.gloenvcha.2008.11.002

Hardoy J and Pandiella G (2009). Urban Poverty and Vulnerability to Climate Change in Latin 
America, Env. Urb., DOI: 10.1177/0956247809103019

Heinrigs P (2010). Security Implications of Climate Change in the Sahel Region: Policy considerations. Paris: Organization for Economic Cooperation and Development Sahel and West Africa Club Secretariat.

Hill, Ruth and Carolina Mejia-Mantilla (2015). Welfare and Shocks in Uganda. Background Paper prepared for World Bank Uganda Poverty Assessment. Washington, D.C.: World Bank.

Huynh LTM,\& Stringer LC (2018). Multi-scale assessment of social vulnerability to climate change: An empirical study in coastal Vietnam. Clim Risk Man., https://doi.org/10.1016/j.crm.2018.02.003

IPCC. (2007). Climate Change 2007: Impacts, Adaptation and Vulnerability. Synthesis Report, 2007, Intergovernmental Panel on Climate Change (IPCC), Cambridge University Press. https://www.ipcc.ch/site/assets/uploads/2018/ 03/ar4 wg2 full report.pdf

Ives JD, Messerli B, and Spiess E (2000). Mountains of the World: A Global Priority, Land Degradation and Development, 2, Parthenon Publishing Group, New York, https://doi.org/10.1002/(SICI)1099$145 \mathrm{X}(200003 / 04) 11: 2<197:: \mathrm{AID}-$ LDR390>3.0.CO;2-U

Iyengar NSand Sudarshan P (1982). A Method of Classifying Regions from Multivariate Data. Eco. Pol. Weekly, Special Article. 20482052.

Koirala S (2015). Livelihood Vulnerability Assessment to the Impacts of SocioEnvironmental Stressors in Raksirang VDC of Makwanpur District Nepal. Master thesis, Norwegian University of Life Sciences, The Department of International Environment and Development Studies, Noragric, retrieved fromhttps://core.ac.uk/download/pdf/521127 32.pdf

Liu J, \& Rasul G (2007). Climate change, the Himalayan Mountains, and ICIMOD. Sust. Moun. Dev., 53,11-14

McWilliams JP, Cote IM, Gill JA, Sutherland WJ and Watkinson AR (2005). Accelerating impacts of temperature-induced coral bleaching in the Caribbean. Eco, 86 (8), 2055-2060. https://doi.org/10.1890/04-1657

Pandey MK, \& Jha A. (2012). Widowhood and health of elderly in India: Examining the role of economic factors using structural equation modelling. Int Review App. Eco., https://doi.org/10.1080/02692171.2011.5871 $\underline{09}$

Panthi J, Aryal S, Dahal P, Bhanddari P, Karakauer NY, and Pandey VP (2015) Livelihood vulnerability approach to assessing climate change impacts on mixed agro-livestock smallholders around the Gandaki River Basin in Nepal. Reg. Env. Change, https://DOI: 10.1007/s10113-0150833-y

Patankar A, and Patwardhan A (2015) Estimating the uninsured losses due to extreme weather events and implications for informal sector vulnerability: a case study of Mumbai, India. Nat. Haz., DOI: 10.1007/s11069-015-1968-3

Rothstein B and Uslaner EM (2005) All for All: Equality, Corruption, and Social Trust, World Politics https://doi.org/10.1353/wp.2006.0022

Roy B, Akter S, Brander L, and Haque E (2007) Socioeconomic Vulnerability and Adaptation to Environmental Risk: A Case Study of Climate Change and Flooding in Bangladesh. Risk Analysis, DOI: 10.1111/j.15396924.2007.00884.x

Schneider SH (2007) Climate Change 2007: Impacts, Adaptation and Vulnerability. InParry, M.L., Canziani, O.F., Palutikof, J.P., van der Linden, P.J., Hanson, C.E. (Eds.) 
Contribution of Working Group II to the Fourth Assessment Report of the Intergovernmental Panel on Climate Change. Cambridge University Press, 779-810.

Shah KU, Dulal HB, Johnson C, Baptiste A. (2013). Understanding livelihood vulnerability to climate change: Applying the livelihood vulnerability index in Trinidad and Tobago, Geoforum, http://DOI: 10.1016/j.geoforum.2013.04.004

Sisay T (2016).Vulnerability of Smallholder Farmers to Climate Change at Dabat and West Belesa Districts, North Gondar, Ethiopia. $J$ Earth Sci. Clim Change, doi:10.4172/2157-7617.1000365

Skoufias Emmanuel ed (2012). The Poverty and Welfare Impacts of Climate Change: Quantifying the Effects, Identifying the Adaptation Strategies. Washington, D.C.: World Bank, DOI: 10.1596/978-0-82139611-7

Tripathi B (2019). India 5th Most Vulnerable To Climate Change Fallouts, Its Poor The Worst Hit, India post, $5^{\text {th }}$ Dec 2019, https://www.indiaspend.com/india-5th-mostvulnerable-to-climate-change-fallouts-itspoor-the-worst-hit/ accessed $12^{\text {th }}$ April 2020

Ward P, and Shively G (2012).Vulnerability, Income Growth and Climate Change, Wor. Dev.https://doi.org/10.1016/j.worlddev.2011. $\underline{11.015}$

Wodon Q, Andrea L, George Jand Nathalie B. (eds.) (2014). Climate Change and Migration: Evidence from the Middle East and North Africa. Washington, D.C.: World Bank. DOI: 10.1596/978-0-8213-9971-2 